\title{
Feasibility of a New Granular Rapid Release Elemental S Fertilizer in Preventing S Deficiency of Canola on a S-Deficient Soil
}

\author{
Sukhdev S. Malhi1 ${ }^{1,2}$, Cecil L. Vera1*, Stewart A. Brandt ${ }^{2}$ \\ ${ }^{1}$ Agriculture and Agri-Food Canada, Melfort, Canada \\ ${ }^{2}$ Northeast Agriculture Research Foundation (NARF), Melfort, Canada \\ Email: “cecil.vera@agr.gc.ca
}

Received 21 July 2014; revised 23 August 2014; accepted 20 September 2014

Copyright (C) 2014 by authors and Scientific Research Publishing Inc.

This work is licensed under the Creative Commons Attribution International License (CC BY).

http://creativecommons.org/licenses/by/4.0/

(c) (i) Open Access

\section{Abstract}

Our previous research has indicated that granular elemental $S$ (ES) fertilizers are not effective in the year of application and also are not consistently as effective as sulphate-S in increasing seed yield of canola in subsequent years, especially when applied at seeding in spring, because of slow dispersion of elemental $S$ particles from granules for subsequent oxidation of ES to sulphate-S. A field experiment was established in autumn 2010 to determine the relative effectiveness of a new rapid release elemental $S$ (RRES, now called Vitasul) fertilizer, in comparison to sulphate-S fertilizer, with various combinations of application times and placement methods (applied at 20 $\mathrm{kg} \cdot S \cdot \mathrm{ha}^{-1}$ ) on seed yield, straw yield, oil and protein concentration in seed, $\mathrm{N}$ and $S$ uptake, partial factor productivity (PFP- $\mathrm{kg} \cdot \mathrm{seed} \cdot \mathrm{kg}^{-1}$ applied $\mathrm{N} \cdot \mathrm{ha}^{-1}$-blanket application of $120 \mathrm{~kg} \cdot \mathrm{N} \cdot \mathrm{ha}^{-1}$ ), $\mathrm{S}$ use efficiency (SUE-increase in $\mathrm{kg} \cdot \mathrm{seed} \cdot \mathrm{kg}^{-1}$ applied $\mathrm{S} \cdot \mathrm{ha}^{-1}$ ) and percent recovery of applied $S$ in seed + straw (\%) of canola in 2011, 2012 and 2013 growing seasons on a S-deficient Gray Luvisol loam soil at Star City, Saskatchewan. The 11 treatments included two granular $S$ sources (RRES and potassium sulphate) and five application time/placement method combinations (broadcast in autumn and incorporated in spring, broadcast in spring pre-tillage [broadcast and incorporated], broadcast in spring pre-emergence, sideband in spring and seedrow-placed in spring), plus a zero$S$ control. There was a significant response of seed yield of canola to applied $S$ in all 3 years, but the responses varied with $S$ source and with application time-placement combinations in different years. Seed yield increased considerably with all sulphate-S treatments compared to the zero-S control, although seed yield tended to be slightly lower in some spring and/or autumn broadcast treatments than the other sulphate-S treatments. Compared to the zero-S control, seed yield also increased significantly with all RRES treatments, but the increase was greater with autumn applied RRES than the spring applied RRES in many cases. Autumn applied RRES produced only slightly lower seed yield but spring applied RRES produced much lower seed yield than the highest

\footnotetext{
*Corresponding author.
} 
yielding spring applied sulphate-S treatments. In 2011, straw yields increased significantly with applied $S$ in some $S$ treatments, but there was no significant effect of $S$ fertilization on straw yield in 2012 and 2013. Oil concentration in canola seed increased only with sulphate-S fertilizer treatments in 2011, and it increased with both sulphate-S and ES sources in 2012 and 2013. There was no effect of any $S$ treatment on the protein concentration in canola seed. The response trends of total $\mathbf{N}$ uptake and PFP were usually similar to seed yield for both $S$ sources, but total $S$ uptake, SUE and \% recovery of applied $S$ were lower with RRES than sulphate-S in many/most cases. In conclusion, the findings suggested the potential of spring broadcast pre-emergence RRES or autumn broadcast RRES in preventing $S$ deficiency in hybrid canola, although seed yields were still slightly lower than the ideal highest yielding spring broadcast/incorporated sulphate-S treatment.

\section{Keywords}

\section{Canola, Elemental S, N Uptake, Oil, Protein, Seed Yield, Sulphate-S, S-Deficiency, S Uptake}

\section{Introduction}

In the Prairie Provinces of Canada, canola is a major cash crop in the Parkland region, where many Gray and Dark Gray soils are deficient or potentially deficient in available S for high crop yields [1] [2]. Because canola has high S requirements, deficiency of S at any growth stage in the growing season can result in a considerable reduction in seed yield. So, a constant supply of available $S$ to canola plants is thus required throughout the growing season in order to prevent any seed yield loss due to S deficiency. Sulphate is the only form of S that plants can use, and previous research has shown that deficiency of $\mathrm{S}$ in rapeseed or canola can be readily prevented or corrected by applying sulphate-S fertilizers [3]-[5].

A number of elemental $S$ fertilizers are now available in the market for commercial use, and may cost less than sulphate-S. However, the elemental S in these fertilizers must be oxidized in soil to plant-available sulphate-S for effective crop use. In previous research studies, granular elemental S fertilizers were found much less effective than sulphate-S fertilizers in improving seed yield of canola on S-deficient soils, especially when applied in spring [6]-[8]. Dispersion of elemental S particles from granular elemental S fertilizers to enhance microbial oxidation of elemental S particles to sulphate-S in soil was considered as the major problem for poor performance of granular elemental S fertilizers [9]. Because of most likely increase in dispersion of elemental S particles in soil over the winter and their subsequent oxidation to sulphate-S in the growing season, autumn-applied elemental S usually produced greater seed yield than spring-applied elemental S but seed yields were still lower and inconsistent than the sulphate-S fertilizers [7].

In other field experiments with spring applied S on S-deficient soils, broadcast/spread surface-application of elemental S fertilizers that contain S particles in suspension or powder formulation prevented S deficiency in canola and produced seed yield comparable to sulphate-S fertilizers [10] [11]. However, suspension or powder formulations of elemental S are not convenient to apply and may not be practical to use on a commercial scale. Now, there is a new granular elemental S fertilizer (rapid release elemental S [RRES], called Vitasul—manufactured by Sulvaris Inc., Calgary, Alberta, Canada), which is expected to oxidize/release adequate amounts of sulphate-S in preventing $S$ deficiency in canola in the growing season. The objective of this study was to determine the relative effectiveness of RRES and sulphate-S fertilizers with various combinations of application times and placement methods on seed yield, straw yield, oil and protein concentration in seed, $\mathrm{N}$ and $\mathrm{S}$ uptake, partial factor productivity (PFP_ $\mathrm{kg} \cdot \mathrm{seed} \cdot \mathrm{kg}^{-1}$ applied $\mathrm{N} \cdot \mathrm{ha}{ }^{-1}$ ), S use efficiency (SUE_increase in $\mathrm{kg} \cdot \mathrm{seed} \cdot \mathrm{kg}^{-1}$ applied S·ha ${ }^{-1}$ ) and percent recovery of applied S in seed + straw (\%) of canola in 2011, 2012 and 2013 growing seasons, and residual sulphate-S and nitrate- $\mathrm{N}$ in the 0 - $60 \mathrm{~cm}$ soil depth in autumn 2013 (after three annual applications of fertilizers) on a S-deficient Gray Luvisol loam soil near Star City, Saskatchewan.

\section{Materials and Methods}

A field experiment was established in autumn 2010 on a Gray Luvisol (Typic Haplocryalf) loam soil near Star City, Saskatchewan, Canada. Soil at this site has shown severe S deficiency in canola in all previous years [7] 
[12], and significant increase in forage yield of timothy from S application [13]. Some characteristics of soils used in these experiments are presented in Table 1. Precipitation in the growing season (May, June, July and August) at the nearest Environment Canada Meteorological Station (AAFC Melfort Research Farm) is given in Table 2. In 2011, the growing season precipitation was below long-term average (especially in May during seeding season and in August during seed formation/filling). In 2012, the growing season precipitation was much above average (with very wet conditions in June and July). In 2013, the growing season precipitation was slightly below-average, but it was well distributed and above-average in June and July during peak growing season, resulting in excellent crop growth and seed yield.

In this study, a randomized complete block design was used to lay out the treatments in four replications. Each plot was $7.5 \mathrm{~m}$ long and $1.8 \mathrm{~m}$ wide. The 11 treatments included two granular S sources (rapid release elemental S [RRES] and potassium sulphate, applied at $20 \mathrm{~kg} \cdot \mathrm{S} \cdot \mathrm{ha}^{-1}$ ) and five application time/placement method combinations [broadcast autumn (surface-broadcast in autumn and then incorporated into soil in spring prior to seeding), broadcast spring pre-tillage (surface-broadcast and then incorporated into soil in spring prior to seeding), broadcast in spring pre-emergence (surface-broadcast soon after seeding), sidebanded in spring at seeding and seedrow-placed in spring at seeding], plus a zero-S control. In autumn 2010, 2011 or 2012, all plots were tilled to about $10 \mathrm{~cm}$ soil depth, and then granular RRES and potassium sulphate were surface broadcast in about mid-October. In spring 2011, 2012 or 2013, the S fertilizers were broadcast on surface prior to tillage in the spring pre-till treatments and all plots received blanket application of $\mathrm{N}$ (34-0-0 at $120 \mathrm{~kg} \cdot \mathrm{N} \cdot \mathrm{ha}^{-1}$ ), P (TSP at $30 \mathrm{~kg} \cdot \mathrm{P} \cdot \mathrm{ha}^{-1}$ ) and $\mathrm{K}\left(\mathrm{KCl}\right.$ at $\left.20 \mathrm{~kg} \cdot \mathrm{K} \cdot \mathrm{ha}^{-1}\right)$. All plots were tilled to incorporate the fertilizers prior to seeding. Spring sideband and seedrow treatments received $\mathrm{S}$ fertilizers at seeding time. Plots were seeded with a double-disc press drill at $17.8 \mathrm{~cm}$ row spacing. Treatments were repeated on the same plots during the duration of this study.

In each plot, the data were recorded on seed and straw yield, oil and protein concentration in seed, concentration and uptake of total $\mathrm{S}$ and total $\mathrm{N}$ in seed and straw every year, and residual sulphate- $\mathrm{S}$ and nitrate- $\mathrm{N}$ in soil at termination in autumn 2013. Seed yield was determined by harvesting $1.25 \mathrm{~m}$ wide and $7.0 \mathrm{~m}$ long strips with a plot combine and straw yield was calculated from hand harvested samples collected from two 1-m long rows in each plot at maturity. The oven dry $\left(60^{\circ} \mathrm{C}\right)$ samples were analyzed for oil, total $\mathrm{N}$ and total $\mathrm{S}$ in seed, and for total $\mathrm{S}$ and total $\mathrm{N}$ in straw. Oil concentration in canola seed was determined using crude fat method [14]. Total $\mathrm{S}$ in seed and straw was determined by digestion of samples in nitric acid-hydrogen peroxide and measuring its concentration in the digest by ICP-AES [15]. Total $\mathrm{N}$ in seed samples was determined by sample digestion and detection of $\mathrm{N}$ by thermal conductivity using a CNS combustion analyzer [16]. Protein concentration was calculated by multiplying the total $\mathrm{N}$ with factor 6.25 [17].

Partial factor productivity (PFP), S use efficiency (SUE) and percent recovery of applied S in seed + straw

Table 1. Some characteristics of soil in autumn 2010 at initiation of the field experiment at Star City, Saskatchewan.

\begin{tabular}{|c|c|c|c|c|c|c|c|c|c|}
\hline Site & $\begin{array}{l}\text { Soil Great } \\
\text { Group }^{\mathrm{Z}}\end{array}$ & Depth (cm) & Texture & $\begin{array}{c}\text { Organic } \\
\text { matter (\%) }\end{array}$ & $\begin{array}{c}\mathrm{pH} \\
\text { (1:2 water) }\end{array}$ & $\begin{array}{l}\text { Nitrate-N } \\
\left(\mathrm{mg}^{\prime} \mathrm{kg}^{-1}\right)\end{array}$ & $\begin{array}{c}\text { Extractable P } \\
\left(\mathrm{mg} \cdot \mathrm{kg}^{-1}\right)\end{array}$ & $\begin{array}{c}\mathrm{SO}_{4}-\mathrm{S} \\
\left(\mathrm{mg} \cdot \mathrm{kg}^{-1}\right)\end{array}$ & $\begin{array}{c}\text { Extractable K } \\
\left(\mathrm{mg} \cdot \mathrm{kg}^{-1}\right)\end{array}$ \\
\hline \multirow[t]{3}{*}{ Star City } & Gray Luvisol & $0-15$ & Loam & 3.1 & 6.6 & 7.5 & 13.9 & 4.5 & 202 \\
\hline & & $15-30$ & & & & 2.4 & 9.6 & 2.3 & 146 \\
\hline & & $30-60$ & & & & 3.0 & 7.8 & 1.6 & 180 \\
\hline
\end{tabular}

${ }^{\mathrm{z}}$ Based on Canadian Soil Classification System.

Table 2. Growing season monthly and total precipitation for the three site-years, and average 30-yr average precipitation and temperature at Star City, Saskatchewan.

\begin{tabular}{|c|c|c|c|c|c|}
\hline \multirow[b]{2}{*}{ Month } & \multicolumn{3}{|c|}{ Precipitation in the growing season $(\mathrm{mm})^{\mathrm{z}}$} & \multicolumn{2}{|c|}{ 30-yr average (Melfort Research Farm) } \\
\hline & 2011 & 2012 & 2013 & Precipitation (mm) & Temperature $\left({ }^{\circ} \mathrm{C}\right)$ \\
\hline May & 10.5 & 59.9 & 22.7 & 45.6 & 9.1 \\
\hline June & 103.5 & 112.0 & 96.9 & 65.8 & 16.9 \\
\hline July & 73.3 & 110.0 & 103.2 & 75.5 & 18.3 \\
\hline August & 10.7 & 68.1 & 10.6 & 56.8 & 19.6 \\
\hline Total & 198.0 & 350.0 & 233.4 & 243.7 & \\
\hline
\end{tabular}

${ }^{\mathrm{z}}$ At the nearest Environment Canada Meteorological Station (Melfort Research Farm). 
were also calculated and used to compare the various $\mathrm{S}$ treatments. PFP was calculated as: [seed yield in $\mathrm{kg} \cdot \mathrm{ha}^{-1}$ in a treatment]/[rate of applied $\mathrm{N}$ in $\mathrm{kg} \cdot \mathrm{N} \cdot \mathrm{ha}^{-1}$ ] [18]. SUE was calculated as: [seed yield in $\mathrm{kg}^{-\mathrm{ha}^{-1}}$ in the S fertilized treatment] - [seed yield in $\mathrm{kg} \mathrm{ha}^{-1}$ in the zero-S control]/[rate of applied S in $\mathrm{kg} \cdot \mathrm{S} \cdot \mathrm{ha}^{-1}$ ]. Percent recovery of applied S in seed + straw was calculated as: 100 [amount of total S in $\mathrm{kg} \cdot \mathrm{S} \cdot \mathrm{ha}^{-1}$ recovered in the S fertilized treatment] - [amount of total S in $\mathrm{kg} \cdot \mathrm{S} \cdot \mathrm{ha}^{-1}$ recovered in the zero-S control]/[rate of applied S in $\mathrm{kg} \cdot \mathrm{S} \cdot \mathrm{ha}^{-1}$ ].

Soil samples from the experimental area were obtained from the 0 - 15, 15 - 30 and 30 - $60 \mathrm{~cm}$ depths in October 2010 (prior to initiation of the field experiment). Each sample was a composite of four cores (4-cm diameter). The soil samples were air dried at room temperature, ground to pass through a 2-mm sieve, and then analyzed for sulphate-S and nitrate-N. Sulphate-S in soil was determined by extraction with $\mathrm{CaCl}_{2}$ and measuring its concentration in the extract by ICP-AES [19]. For nitrate-N, the ground soil samples were extracted using a 1:5 soil: $2 \mathrm{M} \mathrm{KCl}$ solution [20], and the concentration of nitrate- $\mathrm{N}$ in the extract was determined with a Technicon Autoanalyzer II [21].

The data were subjected to analysis of variance (ANOVA) using GLM procedure [22]. For each ANOVA, standard error of the mean (SEM) and significance are reported. Least significant difference $\left(\mathrm{LSD}_{0.05}\right)$ was used to determine significant differences between treatment means.

\section{Results and Discussion}

There was a significant seed yield response of canola to applied S in all 3 years (2011, 2012 and 2013), but seed yields varied with $\mathrm{S}$ source and application time-placement method combination treatments in different years (Table 3).

In 2011, seed yield increased considerably with all sulphate-S treatments compared to the zero-S control, although seed yield tended to be slightly lower in autumn broadcast and spring sideband treatments than other sulphate-S treatments. Compared to the zero-S control, seed yield also increased significantly with all RRES treatments, but the increase was much greater with autumn broadcast RRES than many spring applied RRES treatments. That is, autumn broadcast RRES produced only slightly lower seed yield and most spring applied RRES treatments produced much lower seed yield of canola than the highest yielding spring applied sulphate-S treatments (e.g., broadcast pre-till or seedrow-placed S). This suggests the potential of autumn broadcast RRES in preventing $\mathrm{S}$ deficiency by increasing availability of $\mathrm{S}$ to hybrid canola plants in the first growing season, although slightly less effective than spring broadcast/incorporated sulphate-S in increasing seed yield of canola. In contrast to the findings of the present study, our previous research in Saskatchewan has shown that autumn or

Table 3. Seed yield of canola with rapid release elemental S (RRES) and sulphate-S fertilizers applied at $20 \mathrm{~kg} \cdot \mathrm{S} \cdot \mathrm{ha}{ }^{-1}$ with various combinations of application time and placement method in 2011, 2012 and 2013 on a S-deficient soil at Star City, Saskatchewan.

\begin{tabular}{clcccc}
\hline \multicolumn{1}{c}{ Treatment } & \multicolumn{5}{c}{ Seed Yield $\left(\mathrm{kg}^{\prime}\right.$ ha $\left.^{-1}\right)$} \\
\hline No. & S Source/Time/Method & 2011 & 2012 & 2013 & Mean \\
\hline 1 & Control (No S Fertilizer) & 2021 & 1361 & 2759 & 2127 \\
2 & RRES Broadcast Autumn & 2836 & 1860 & 3872 & 2856 \\
3 & RRES Broadcast Spring Pre-Till & 2451 & 1666 & 4028 & 2715 \\
4 & RRES Broadcast Spring Pre-Emergence & 2692 & 1929 & 4100 & 2907 \\
5 & RRES Spring Sideband & 2521 & 1586 & 3854 & 2666 \\
6 & RRES Spring Seedrow-Placed & 2472 & 1592 & 3846 & 2637 \\
7 & Potassium Sulphate Broadcast Autumn & 2858 & 1829 & 3980 & 2889 \\
8 & Potassium Sulphate Broadcast Spring Pre-Till & 2985 & 1952 & 4215 & 3051 \\
9 & Potassium Sulphate Broadcast Spring Pre-Emergence & 2939 & 1907 & 3933 & 2926 \\
10 & Potassium Sulphate Spring Sideband & 2830 & 1948 & 4097 & 2958 \\
11 & Potassium Sulphate Spring Seedrow-Placed & 2993 & 1661 & 4013 & 2889 \\
& LSD ${ }_{0.05}$ & 425 & 228 & 337 & 207 \\
\hline
\end{tabular}


spring applied granular ES fertilizers were not effective in increasing seed yield of canola in the first year of application, although autumn applied ES was more effective than spring applied ES, but it was still significantly less effective than spring applied sulphate-S in most cases [7] [8].

In 2012, seed yield was much lower (63\% of the three year mean) than in 2011 and 2013, probably due to higher precipitation (43\% higher than normal) and poor soil drainage. This year there was a significant (but moderate) seed yield response of canola to all spring applied sulphate-S treatments, and seed yield tended to be slightly lower in the autumn broadcast sulphate-S treatment and significantly lower in the spring seedrow-placed sulphate-S treatment than the other spring sulphate-S treatments (Table 3). Among sulphate-S treatments, spring seedrow-placed S produced the lowest seed yield, which was probably due to toxic effects of potassium sulphate on emergence or early growth of seedlings in the seedrow but we did not make any plant counts on seedling emergence. Seed yield also increased significantly (but moderately) with all RRES treatments compared to the zero-S control, but the increases were significantly greater with autumn broadcast RRES and more so with spring pre-emergence broadcast RRES than other spring applied RRES treatments. Autumn broadcast RRES produced only slightly lower, spring pre-emergence broadcast RRES produced similar, and spring applied pretill, sideband and seedrow-placed RRES produced much lower seed yield than the highest yielding spring applied sulphate-S broadcast pre-till or sideband S treatments. Earlier research on canola in Saskatchewan and Alberta has shown that autumn applied granular ES fertilizers was more effective than spring applied granular ES fertilizers, but autumn applied ES was not consistently as effective as spring applied sulphate-S fertilizer, even after multi-year annual applications [7] [8] [10]. Our previous research on canola in Saskatchewan has also shown substantial increase in seed yield of canola when liquid ES fertilizer was spray-broadcast on soil surface after seeding [7]. This suggests that physical dispersion of S particles from the ES granules, which is the major limitation for exposure of ES particles to oxidation to sulphate-S under Parkland region climatic conditions, can be overcome by surface-broadcast of granular ES fertilizer immediately after seeding. Similarly, our present findings also suggest the potential of spring broadcast pre-emergence RRES in preventing $\mathrm{S}$ deficiency in hybrid canola at least after second annual application, when seed yield was similar to spring broadcast/incorporated sulphate-S. In summary, our findings suggested the potential of spring broadcast pre-emergence RRES or autumn broadcast RRES in preventing $\mathrm{S}$ deficiency in hybrid canola after second annual application, although seed yield was slightly lower (not significantly) than the spring broadcast/incorporated sulphate-S.

In 2013, there was a marked seed yield response of canola to spring applied sulphate-S, and seed yield tended to be slightly greater in the spring broadcast pre-till sulphate-S treatment than the other spring sulphate-S treatments (Table 3). Among sulphate-S treatments, spring pre-emergence broadcast tended to produce lowest seed yield. Compared to zero-S control, seed yield also increased considerably with all RRES treatments, but the increases tended to be lower with autumn broadcast RRES and spring sideband or seedrow-placed RRES treatments than spring pre-emergence RRES or spring pre-till RRES treatments. Autumn broadcast RRES, and spring sideband and seedrow-placed RRES produced much lower seed yield than the highest yielding spring applied sulphate-S broadcast pre-till S treatment. The 3-year findings suggest the potential of spring pre-emergence RRES in preventing $\mathrm{S}$ deficiency in hybrid canola consistently after second and third annual applications, although seed yields were slightly lower (not significantly) than the spring broadcast/incorporated sulphate-S.

On the average of 3 years, there was a significant increase in canola seed yield from applied S compared to zero-S control in all cases, but seed yields varied with $\mathrm{S}$ source and/or application time-method combination (Table 3). Among the sulphate-S treatments, spring broadcast pre-till sulphate-S treatment produced the greatest seed yield, which was closely followed by spring sideband and spring pre-emergence broadcast treatments, and then autumn broadcast and spring seedrow-placed S treatments producing similar and lowest seed yield. The poor performance (although not significant) of autumn applied/broadcast sulphate-S compared to spring preemergence broadcast sulphate-S was probably due to over-winter loss of $S$ in early spring by leaching from the soil sulphate-S pool. In the case of spring pre-emergence broadcast sulphate-S, it is possible that a small portion of applied S may have been stranded in the surface soil and did not become available to the crop in the early growing season on this S-deficient soil. Similarly, it is possible that a small portion of applied S for the sidebanded sulphate-S may also have not become available to crop in the early growing season. The relative poor performance of seedrow-placed sulphate-S could be due to the toxic effect of sulphate-S on seedling emergence and/or their early growth (but we did not make any plant counts). Among the RRES treatments, spring preemergence produced the highest seed yield, and it was closely followed by autumn broadcast, with the lowest seed yields from spring pre-till broadcast, spring sideband and spring seedrow-placed treatments (Table 3). 
Overall, the findings suggest the potential of spring pre-emergence broadcast RRES or autumn broadcast RRES in preventing $\mathrm{S}$ deficiency in hybrid canola, although seed yield was still slightly lower than the spring pre-till broadcast/incorporated sulphate-S treatment which produced the greatest seed yield from applied S. In the case of RRES, autumn broadcast was considered ideal time/method for diffusion of ES particles from granules and then oxidation of ES to sulphate-S over the winter, and was expected to be more effective than spring preemergence RRES and/or as effective as spring applied sulphate-S fertilizer, but it was still slightly less effective than those treatments, especially spring-applied sulphate-S. It is possible that a small portion of ES that was oxidized to sulphate-S over the winter from autumn broadcast RRES, may have been lost by runoff and/or leaching in early spring after snow melting. The relative poor performance of spring pre-till broadcast RRES compared to spring pre-emergence broadcast RRES could be due to the fact that ES granules after incorporation in pre-till treatment may have stayed intact in the soil, resulting in less diffusion and subsequently poor oxidation of ES particles to sulphate-S compared to ES granules that were deposited on the soil surface, being exposed to wetting/drying and temperature, ideal for diffusion and oxidation, in the case of spring pre-emergence broadcast RRES, as also suggested by Solberg et al. [9].

Unlike seed yield, there was no significant effect of applied S source and/or timing of application on straw yield in all three years in the present study (data not shown). In contrast, previous research has shown a significant positive response of both straw and seed yield to applied sulphate-S fertilizer at some sites/site-years [4] [7] [8] [23]. In the present study, straw yields ranged from 4745 to $6879 \mathrm{~kg} \cdot \mathrm{ha}^{-1}$ in 2011, from 3701 to $5059 \mathrm{~kg} \cdot \mathrm{ha}^{-1}$ in 2012 and from 7587 to 10,446 kg.ha ${ }^{-1}$ in 2013. In 2012, straw yield was highest with spring pre-till RRES and lowest with spring sideband RRES. In 2013, straw yield was highest with zero-S treatment and lowest with autumn broadcast RRES. These straw yield results suggest that RRES in these treatments increased the availability of $\mathrm{S}$ to plants in the later growing season and increased straw yield, but this did not translate into seed yield.

Oil concentration in canola seed increased with sulphate-S application in most cases in all 3 years, but RRES showed significant beneficial effect on oil concentration in canola seed only in 2012 and 2013 (Table 4). In 2011, oil concentration in canola seed increased with almost all sulphate-S fertilizer treatments and tended to increase with only autumn broadcast RRES and spring pre-emergence RRES treatments. In 2012, oil concentration in canola seed increased in almost all sulphate-S (except seedrow-placed sulphate-S) and in all RRES treatments. Spring pre-emergence RRES gave the highest oil concentration in canola seed. In 2013, oil concentration in canola seed increased in all sulphate-S and RRES treatments. On the average of 3 years, oil concentration in canola seed increased in all S treatments, regardless of $\mathrm{S}$ source, suggesting that $\mathrm{S}$ fertilization can increase oil concentration in canola seed when S deficiency exists in canola. Earlier research studies in Canada (Saskatche-

Table 4. Concentration of oil in seed of canola with rapid release elemental S (RRES) and sulphate-S fertilizers applied at 20 $\mathrm{kg} \cdot \mathrm{S} \cdot \mathrm{ha}^{-1}$ with various combinations of application time and placement method in 2011, 2012 and 2013 on a S-deficient soil at Star City, Saskatchewan.

\begin{tabular}{|c|c|c|c|c|c|}
\hline \multicolumn{2}{|r|}{ Treatment } & \multicolumn{4}{|c|}{ Oil Concentration in Seed $\left(\mathrm{g} \cdot \mathrm{kg}^{-1}\right)$} \\
\hline No. & S Source/Time/Method & 2011 & 2012 & 2013 & Mean \\
\hline 1 & Control (No S Fertilizer) & 461 & 443 & 450 & 451 \\
\hline 2 & RRES Broadcast Autumn & 468 & 464 & 481 & 471 \\
\hline 3 & RRES Broadcast Spring Pre-Till & 460 & 460 & 480 & 467 \\
\hline 4 & RRES Broadcast Spring Pre-Emergence & 469 & 482 & 481 & 477 \\
\hline 5 & RRES Spring Sideband & 461 & 463 & 469 & 464 \\
\hline 6 & RRES Spring Seedrow-Placed & 458 & 466 & 474 & 466 \\
\hline 7 & Potassium Sulphate Broadcast Autumn & 481 & 461 & 484 & 475 \\
\hline 8 & Potassium Sulphate Broadcast Spring Pre-Till & 478 & 470 & 482 & 477 \\
\hline 9 & Potassium Sulphate Broadcast Spring Pre-Emergence & 483 & 465 & 474 & 474 \\
\hline 10 & Potassium Sulphate Spring Sideband & 471 & 475 & 483 & 476 \\
\hline \multirow[t]{3}{*}{11} & Potassium Sulphate Spring Seedrow-Placed & 480 & 448 & 480 & 469 \\
\hline & $\mathrm{LSD}_{0.05}$ & 12 & 16 & 9 & 9 \\
\hline & SEM & $4.2^{* * *}$ & $5.6^{* *}$ & $3.2^{* * *}$ & $3.0^{* * *}$ \\
\hline
\end{tabular}


wan, Alberta and Manitoba) and USA (Montana) have also shown increase of oil concentration in canola seed with sulphate-S fertilizer application [7] [8] [11] [23]-[27], but there was little beneficial effect of ES fertilizers on oil concentration in canola seed [8] [26] [27].

There was no effect of any S fertilizer treatment on protein concentration in canola seed in 2011 (Table 5). In 2012, protein concentration in canola seed increased significantly only in seedrow-placed sulphate-S treatment. This increase in protein concentration of canola seed was most likely due to the decrease in seed yield because of detrimental effect of seedrow-placed $S$ in this treatment. There was no significant effect of $S$ fertilizer on protein concentration in canola seed in 2013, and also on the 3-yr average protein concentration. Similarly, our other research has also reported no effect of S application on protein concentration in canola seed [7] [8] [11] [23] [25].

The response trends of total $\mathrm{N}$ uptake in seed + straw to applied $\mathrm{S}$ were significant in all 3 years and were generally similar to seed yield, and also varied with $\mathrm{S}$ source and application time-placement treatments in different years (Table 6). In 2011, total N uptake in seed + straw increased significantly in all treatments, and it was highest for spring sideband RRES treatment, followed very closely by spring seed-row placed sulphate-S treatment. In 2012, there was a significant increase in total $\mathrm{N}$ uptake in seed + straw in almost all treatments except sideband RRES, although spring sideband or seedrow-placed RRES and spring seedrow-placed sulphate-S gave the lowest total $\mathrm{N}$ uptake in seed + straw. Spring applied pre-till and sideband sulphate-S had the highest total $\mathrm{N}$ uptake in seed + straw. In 2013, total $\mathrm{N}$ uptake in seed + straw increased significantly with applied S in most treatments except autumn broadcast RRES and sulphate-S. On the 3-yr average, total $\mathrm{N}$ uptake in seed + straw increased significantly with all S treatments, regardless of S source and time-method combination. Other earlier research has also shown increase of total $\mathrm{N}$ uptake in canola seed and/or straw with $\mathrm{S}$ fertilizer application, mainly due to increase in yield [11] [23].

Total S uptake in seed + straw increased significantly in all sulphate-S treatments in all years, but with RRES it increased significantly in only few treatments (e.g., RRES broadcast autumn, RRES broadcast spring pre-till and RRES broadcast spring pre-emergence) in 2012 and 2013, and also total S uptake was generally lower with RRES than sulphate-S (Table 7). The highest total S uptake in seed + straw was with spring seedrow-placed sulphate-S in 2011 and with spring pre-till sulphate-S in 2012 and 2013. Among the RRES treatments, total S uptake in seed + straw was highest with broadcast spring pre-emergence in 2011, and with autumn broadcast in 2012 and 2013, but it was still less than the spring broadcast/incorporated sulphate-S treatment, even after three annual applications. Previous research studies in Canada (Saskatchewan and Manitoba) and USA (Montana) have shown increase of total S uptake in canola seed and/or straw with $S$ fertilizer application, due to increase in

Table 5. Concentration of protein in seed of canola with rapid release elemental S (RRES) and sulphate-S fertilizers applied at $20 \mathrm{~kg} \cdot \mathrm{S} \cdot \mathrm{ha}^{-1}$ with various combinations of application time and placement method in 2011, 2012 and 2013 on a S-deficient soil at Star City, Saskatchewan.

\begin{tabular}{|c|c|c|c|c|c|}
\hline \multicolumn{2}{|r|}{ Treatment } & \multicolumn{4}{|c|}{ Protein Concentration in Seed $\left(\mathrm{g} \cdot \mathrm{kg}^{-1}\right)$} \\
\hline No. & S Source/Time/Method & 2011 & 2012 & 2013 & Mean \\
\hline 1 & Control (no S fertilizer) & 225 & 232 & 216 & 224 \\
\hline 2 & RRES Broadcast Autumn & 224 & 234 & 208 & 222 \\
\hline 3 & RRES Broadcast Spring Pre-Till & 229 & 232 & 215 & 225 \\
\hline 4 & RRES Broadcast Spring Pre-Emergence & 222 & 226 & 222 & 223 \\
\hline 5 & RRES Spring Sideband & 223 & 227 & 222 & 225 \\
\hline 6 & RRES Spring Seedrow-Placed & 226 & 231 & 218 & 225 \\
\hline 7 & Potassium Sulphate Broadcast Autumn & 224 & 236 & 210 & 223 \\
\hline 8 & Potassium Sulphate Broadcast Spring Pre-Till & 220 & 234 & 211 & 222 \\
\hline 9 & Potassium Sulphate Broadcast Spring Pre-Emergence & 218 & 236 & 207 & 221 \\
\hline 10 & Potassium Sulphate Spring Sideband & 225 & 228 & 220 & 224 \\
\hline \multirow[t]{3}{*}{11} & Potassium Sulphate Spring Seedrow-Placed & 219 & 245 & 213 & 226 \\
\hline & $\mathrm{LSD}_{0.05}$ & 9 & 8 & 23 & 9 \\
\hline & SEM & $3.1^{\text {ns }}$ & $2.6^{* *}$ & $8.1^{\mathrm{ns}}$ & $3.3^{\text {ns }}$ \\
\hline
\end{tabular}


Table 6. Total N uptake in seed + straw of canola with rapid release elemental S (RRES) and sulphate-S fertilizers applied at $20 \mathrm{~kg} \cdot \mathrm{S} \cdot \mathrm{ha}^{-1}$ with various combinations of application time and placement method in 2011, 2012 and 2013 on a S-deficient soil at Star City, Saskatchewan.

\begin{tabular}{clcccc}
\hline \multicolumn{1}{c}{ Treatment } & \multicolumn{3}{c}{ Total N Uptake in Seed + Straw $\left(\mathrm{kg}^{\prime} \mathrm{ha}^{-1}\right)$} \\
\hline No. & S Source/Time/Method & 2011 & 2012 & 2013 & Mean \\
\hline 1 & Control (No S Fertilizer) & 99 & 81 & 150 & 110 \\
2 & RRES Broadcast Autumn & 122 & 109 & 165 & 132 \\
3 & RRES Broadcast Spring Pre-Till & 124 & 106 & 179 & 137 \\
4 & RRES Broadcast Spring Pre-Emergence & 128 & 100 & 186 & 138 \\
5 & RRES Spring Sideband & 133 & 92 & 181 & 135 \\
6 & RRES Spring Seedrow-Placed & 119 & 94 & 176 & 130 \\
7 & Potassium Sulphate Broadcast Autumn & 122 & 105 & 172 & 133 \\
8 & Potassium Sulphate Broadcast Spring Pre-Till & 127 & 114 & 187 & 143 \\
9 & Potassium Sulphate Broadcast Spring Pre-Emergence & 127 & 104 & 177 & 136 \\
10 & Potassium Sulphate Spring Sideband & 128 & 112 & 182 & 141 \\
11 & Potassium Sulphate Spring Seedrow-Placed & 132 & 96 & 179 & 136 \\
& LSD ${ }_{0.05}$ & 18 & 13 & 25 & 10 \\
& SEM & $6.3^{0.06}$ & $4.7^{* * *}$ & $8.5^{0.18}$ & $3.6^{* * *}$ \\
\hline
\end{tabular}

Table 7. Total S uptake in seed + straw of canola with rapid release elemental S (RRES) and sulphate-S fertilizers applied at $20 \mathrm{~kg} \cdot \mathrm{S} \cdot \mathrm{ha}^{-1}$ with various combinations of application time and placement method in 2011, 2012 and 2013 on a S-deficient soil at Star City, Saskatchewan.

\begin{tabular}{clcccc}
\hline \multicolumn{1}{c}{ Treatment } & \multicolumn{3}{c}{ Total S Uptake in Seed + Straw $\left(\mathrm{kg}^{\circ} \mathrm{ha}^{-1}\right)$} \\
\hline No. & S Source/Time/Method & 2011 & 2012 & 2013 & Mean \\
\hline 1 & Control (No S Fertilizer) & 14.8 & 10.1 & 12.5 & 12.5 \\
2 & RRES Broadcast Autumn & 17.3 & 18.5 & 18.2 & 18.0 \\
3 & RRES Broadcast Spring Pre-Till & 17.0 & 16.4 & 17.7 & 17.1 \\
4 & RRES Broadcast Spring Pre-Emergence & 19.1 & 15.0 & 17.7 & 17.2 \\
5 & RRES Spring Sideband & 18.4 & 11.9 & 14.9 & 14.6 \\
6 & RRES Spring Seedrow-Placed & 15.2 & 12.2 & 15.0 & 14.2 \\
7 & Potassium Sulphate Broadcast Autumn & 23.4 & 18.8 & 23.7 & 22.0 \\
8 & Potassium Sulphate Broadcast Spring Pre-Till & 23.5 & 21.0 & 29.9 & 24.8 \\
9 & Potassium Sulphate Broadcast Spring Pre-Emergence & 22.7 & 19.1 & 27.4 & 23.1 \\
10 & Potassium Sulphate Spring Sideband & 21.1 & 18.4 & 22.6 & 20.7 \\
11 & Potassium Sulphate Spring Seedrow-Placed & 24.7 & 17.3 & 24.9 & 22.3 \\
& LSD ${ }_{0.05}$ & 4.9 & 3.4 & 5.0 & 3.0 \\
& SEM $^{*}$ & $1.68^{* * *}$ & $1.16^{* * *}$ & $1.7^{* * *}$ & $1.05^{* * *}$ \\
\hline
\end{tabular}

both yield and concentration of total S in canola plants [7] [8] [11] [23]-[27]. In our previous research in Saskatchewan, total S uptake in canola was usually much lower with ES fertilizers than sulphate-S fertilizers [7] [8] [11].

There was a significant increase in PFP with applied S for both S sources compared to zero-S control in all 3 years (Table 8). The response trends of PFP to applied S fertilizers were essentially similar to seed yield, although the magnitude of response varied in different years. In 2011, the PFP values ranged from 23.6 to $24.9 \mathrm{~kg}$ seed $\mathrm{kg}^{-1}$ applied $\mathrm{N}$ for sulphate-S treatments, with small differences among treatments. For the RRES treatments, the PFP values ranged from 20.4 to $23.6 \mathrm{~kg}$ seed $\mathrm{kg}^{-1}$ applied $\mathrm{N}$, with the highest PFP with autumn broadcast treatment. In 2012, the PFP values ranged from 13.8 to $16.3 \mathrm{~kg}$ seed $\mathrm{kg}^{-1}$ applied N for sulphate-S 
Table 8. Partial factor productivity (PFP for N applied at $120 \mathrm{~kg} \cdot \mathrm{N} \cdot \mathrm{ha} \mathrm{a}^{-1}$ as a blanket application) for seed yield of canola with rapid release elemental S (RRES) and sulphate-S fertilizers applied at $20 \mathrm{~kg} \cdot \mathrm{S} \cdot \mathrm{ha}^{-1}$ with various combinations of application time and placement method in 2011, 2012 and 2013 on a S-deficient soil at Star City, Saskatchewan.

\begin{tabular}{|c|c|c|c|c|c|}
\hline \multicolumn{2}{|r|}{ Treatment } & \multicolumn{4}{|c|}{ PFP (kg Seed kg ${ }^{-1}$ Applied $\cdot \mathrm{N} \mathrm{ha}^{-1}$ ) } \\
\hline No. & S Source/Time/Method & 2011 & 2012 & 2013 & Mean \\
\hline 1 & Control (No S Fertilizer) & 16.8 & 11.8 & 25.0 & 17.7 \\
\hline 2 & RRES Broadcast Autumn & 23.6 & 15.5 & 32.3 & 23.8 \\
\hline 3 & RRES Broadcast Spring Pre-Till & 20.4 & 13.9 & 33.6 & 22.6 \\
\hline 4 & RRES Broadcast Spring Pre-Emergence & 22.4 & 16.1 & 34.2 & 24.2 \\
\hline 5 & RRES Spring Sideband & 21.0 & 13.2 & 32.1 & 22.2 \\
\hline 6 & RRES Spring Seedrow-Placed & 20.6 & 13.3 & 32.1 & 22.0 \\
\hline 7 & Potassium Sulphate Broadcast Autumn & 23.8 & 15.2 & 33.2 & 24.1 \\
\hline 8 & Potassium Sulphate Broadcast Spring Pre-Till & 24.9 & 16.3 & 35.1 & 25.4 \\
\hline 9 & Potassium Sulphate Broadcast Spring Pre-Emergence & 24.5 & 15.9 & 32.8 & 24.4 \\
\hline 10 & Potassium Sulphate Spring Sideband & 23.6 & 16.2 & 34.1 & 24.7 \\
\hline \multirow[t]{3}{*}{11} & Potassium Sulphate Spring Seedrow-Placed & 24.9 & 13.8 & 33.4 & 24.1 \\
\hline & $\mathrm{LSD}_{0.05}$ & 3.5 & 1.9 & 2.8 & 1.7 \\
\hline & SEM & $1.22^{* *}$ & $0.65^{* * *}$ & $0.97^{* * *}$ & $0.60^{* * *}$ \\
\hline
\end{tabular}

treatments, with the lowest PFP with spring seedrow-placed S. For the RRES treatments, the PFP values ranged from 13.2 to $16.1 \mathrm{~kg}$ seed $\mathrm{kg}^{-1}$ applied $\mathrm{N}$, with the highest PFP with autumn broadcast or spring pre-emergence $\mathrm{S}$ treatment. In 2013, the PFP values ranged from 32.8 (spring broadcast pre-emergence) to 35.1 (spring broadcast pre-till) $\mathrm{kg}$ seed $\mathrm{kg}^{-1}$ applied $\mathrm{N}$ for sulphate-S treatments. For the RRES treatments, the PFP values ranged from 32.1 (spring sideband or spring seedrow-placed) to 34.2 (spring broadcast pre-emergence) $\mathrm{kg} \cdot \mathrm{seed}^{\mathrm{kg}} \mathrm{kg}^{-1} \mathrm{ap}-$ plied N. On the average of 3 years, the PFP values ranged from 24.1 (autumn broadcast or spring seedrowplaced) to 25.4 (spring broadcast pre-till) $\mathrm{kg}$ seed $\mathrm{kg}^{-1}$ applied $\mathrm{N}$ for sulphate-S treatments and from 22.0 (spring seedrow-placed) to 24.2 (spring broadcast pre-emergence) $\mathrm{kg}$ seed $\mathrm{kg}^{-1}$ applied $\mathrm{N}$ for RRES treatments.

The SUE for seed yield ( $\mathrm{kg}$ seed $\mathrm{kg}^{-1}$ applied $\mathrm{S} \cdot \mathrm{ha}^{-1}$ ) varied with $\mathrm{S}$ source and application time-placement treatments in different years (Table 9). In 2011, the SUE for sulphate-S was highest for spring seedrow-placed (48.6) and spring pre-till (48.2), followed by spring pre-emergence (45.9), with the lowest SUE with autumn broadcast (41.9) or spring sideband (40.5). For RRES, autumn broadcast gave the highest SUE (40.8) but it was significantly lower than the best sulphate-S treatments. In 2012, the SUE for sulphate-S ranged from 15.0 (spring seedrow-placed) to 29.5 (spring pre-till). For RRES, the SUE ranged from 11.2 (spring sideband) to 28.4 (spring-pre-emergence). In 2013, the SUE for sulphate-S ranged from 46.7 (broadcast spring pre-emergence) to 60.8 (spring pre-till). For RRES, the SUE ranged from 42.3 (spring seedrow-placed) to 55.0 (spring-pre-emergence). On the average of 3 years, the SUE ranged from 40.0 (spring-pre-emergence) to 46.2 (spring pre-till) for sulphate-S, and from 25.5 (spring seedrow-placed) to 39.0 (spring-pre-emergence) for RRES.

Like SUE, \% recovery of applied S also varied with S source and application time-placement treatments in different years (Table 10). In 2011, recovery of applied sulphate-S in seed + straw ranged 31.6\% to 49.6\%, with the highest $\mathrm{S}$ recovery with spring seedrow-placed $\mathrm{S}$ and lowest with spring sideband S. For RRES, recovery of applied S ranged from $1.7 \%$ to $21.3 \%$, and was highest for spring pre-emergence treatment and lowest for spring seedrow-placed S. In 2012, recovery of applied sulphate-S in seed + straw ranged from $35.9 \%$ to $54.6 \%$, with the highest S recovery with spring pre-till S. For RRES, recovery of applied S ranged from $8.9 \%$ to $41.7 \%$, with the highest recovery autumn broadcast treatment and lowest for spring sideband S. In 2013, recovery of applied S ranged from $50.2 \%$ (spring sideband) to $87.1 \%$ (spring pre-till) for sulphate-S and from 11.9 (spring sideband) to 28.4 (broadcast autumn) for RRES. On the average of 3 years, recovery of applied S ranged from $41.1 \%$ (spring sideband) to $61.7 \%$ (spring pre-till) for sulphate-S and from 11.0 (spring sideband) to 27.4 (broadcast autumn) for RRES.

Overall, the response trends of total $\mathrm{N}$ uptake and PFP were usually similar to seed yield for both $\mathrm{S}$ sources, but total S uptake, SUE and \% recovery of applied S in seed + straw were lower with RRES than sulphate-S in 
Table 9. Sulphur use efficiency (SUE) for seed yield of canola with rapid release elemental S (RRES) and sulphate-S fertilizers applied at $20 \mathrm{~kg} \cdot \mathrm{S} \cdot \mathrm{ha}^{-1}$ with various combinations of application time and placement method in 2011, 2012 and 2013 on a S-deficient soil at Star City, Saskatchewan.

\begin{tabular}{|c|c|c|c|c|c|}
\hline \multicolumn{2}{|r|}{ Treatment } & \multicolumn{4}{|c|}{ SUE (kg.Seed $\cdot \mathrm{kg}^{-1}$ Applied S·ha ${ }^{-1}$ ) } \\
\hline No. & S Source/Time/Method & 2011 & 2012 & 2013 & Mean \\
\hline 2 & RRES Broadcast Autumn & 40.8 & 25.0 & 43.6 & 36.5 \\
\hline 3 & RRES Broadcast Spring Pre-Till & 21.5 & 15.2 & 51.4 & 29.4 \\
\hline 4 & RRES Broadcast Spring Pre-Emergence & 33.6 & 28.4 & 55.0 & 39.0 \\
\hline 5 & RRES Spring Sideband & 25.1 & 11.2 & 42.7 & 27.0 \\
\hline 6 & RRES Spring Seedrow-Placed & 22.6 & 11.6 & 42.3 & 25.5 \\
\hline 7 & Potassium Sulphate Broadcast Autumn & 41.9 & 23.4 & 49.0 & 38.1 \\
\hline 8 & Potassium Sulphate Broadcast Spring Pre-Till & 48.2 & 29.5 & 60.8 & 46.2 \\
\hline 9 & Potassium Sulphate Broadcast Spring Pre-Emergence & 45.9 & 27.3 & 46.7 & 40.0 \\
\hline 10 & Potassium Sulphate Spring Sideband & 40.5 & 29.4 & 54.8 & 41.6 \\
\hline \multirow[t]{3}{*}{11} & Potassium Sulphate Spring Seedrow-Placed & 48.6 & 15.0 & 50.7 & 38.1 \\
\hline & $\mathrm{LSD}_{0.05}$ & 20.2 & 11.3 & 14.7 & 8.5 \\
\hline & SEM & $6.96^{*}$ & $3.90^{* *}$ & $5.07^{\mathrm{ns}}$ & $29.2^{* * *}$ \\
\hline
\end{tabular}

Table 10. Percent recovery of applied S in seed + straw of canola with rapid release elemental S (RRES) and sulphate-S fertilizers applied at $20 \mathrm{~kg} \cdot \mathrm{S} \cdot \mathrm{ha}^{-1}$ with various combinations of application time and placement method in 2011, 2012 and 2013 on a S-deficient soil at Star City, Saskatchewan.

\begin{tabular}{|c|c|c|c|c|c|}
\hline \multicolumn{2}{|r|}{ Treatment } & \multicolumn{4}{|c|}{ Recovery of Applied S in Seed + Straw (\%) } \\
\hline No. & S Source/Time/Method & 2011 & 2012 & 2013 & Mean \\
\hline 2 & RRES Broadcast Autumn & 12.2 & 41.7 & 28.4 & 27.4 \\
\hline 3 & RRES Broadcast Spring Pre-Till & 10.8 & 31.6 & 26.0 & 22.8 \\
\hline 4 & RRES Broadcast Spring Pre-Emergence & 21.3 & 24.3 & 25.9 & 23.8 \\
\hline 5 & RRES Spring Sideband & 14.4 & 8.9 & 11.9 & 11.0 \\
\hline 6 & RRES Spring Seedrow-Placed & 1.7 & 10.6 & 12.6 & 8.3 \\
\hline 7 & Potassium Sulphate Broadcast Autumn & 42.7 & 43.4 & 56.1 & 47.4 \\
\hline 8 & Potassium Sulphate Broadcast Spring Pre-Till & 43.3 & 54.6 & 87.1 & 61.7 \\
\hline 9 & Potassium Sulphate Broadcast Spring Pre-Emergence & 39.2 & 45.1 & 74.2 & 52.8 \\
\hline 10 & Potassium Sulphate Spring Sideband & 31.6 & 41.5 & 50.2 & 41.1 \\
\hline \multirow[t]{3}{*}{11} & Potassium Sulphate Spring Seedrow-Placed & 49.6 & 35.9 & 61.8 & 49.1 \\
\hline & $\mathrm{LSD}_{0.05}$ & 22.6 & 17.5 & 25.8 & 15.0 \\
\hline & SEM & $7.77^{* *}$ & $6.04^{* * *}$ & $8.90^{* * *}$ & $5.17^{* * *}$ \\
\hline
\end{tabular}

many/most cases. It is possible that RRES may have supplied near sufficient/adequate amounts of available $\mathrm{S}$ to canola plants during the growing season for seed yield but not for total S uptake in seed + straw, resulting in lower total S uptake, SUE and \% recovery of applied S in seed + straw than the highest yielding spring applied sulphate-S fertilizer (broadcast/incorporated) treatment.

\section{Conclusion}

There was a significant seed yield response of hybrid canola to applied S from both sulphate-S and RRES sources in all 3 years. Oil concentration in canola seed increased with both S sources in 2012 and 2013, but it increased only with sulphate-S in 2011. There was no effect of any S treatment on the protein concentration in canola seed. The response trends of total $\mathrm{N}$ uptake and PFP were usually similar to seed yield for both $\mathrm{S}$ sources, but total S uptake, SUE and \% recovery of applied S were lower with RRES than sulphate-S in many/most cases. 
The findings of our study on a S-deficient soil suggest that the ideal S application is sulphate-S broadcast, incorporated into soil prior to seeding in spring. Our findings also suggest the potential of autumn broadcast RRES and spring pre-emergence broadcast RRES in preventing S deficiency in hybrid canola, although seed yields are slightly lower than the ideal highest yielding spring broadcast/incorporated sulphate-S treatment. Our findings are based on one site/soil, so there is a need of additional future research to verify our findings and improve effectiveness of Vitasul (commercial name of RRES) further under varied soil types, climatic and crop growing conditions. For producers who are planning to use Vitasul on their farms, they should try it on a small scale (for their own satisfaction) and find out if this $\mathrm{S}$ fertilizer is working/effective in preventing $\mathrm{S}$ deficiency in their crop, especially canola, under their particular soil, crop and farm/climatic situations/conditions.

\section{Acknowledgements}

Thanks to Sulvaris Inc., Calgary, Alberta, for financial assistance, and D. Leach and K. Strukoff for technical help.

\section{References}

[1] Bettany, J.R., Janzen, H.H. and Stewart, J.W.B. (1983) Sulphur Deficiency in the Prairie Provinces of Canada. Proceedings of International Sulphur '82 Conference, 1, 787-800.

[2] Doyle, P.J. and Cowell, L.E. (1993) Sulphur. In: Rennie, D.A., Campbell, C.A. and Roberts, T.L., Eds., Impact of Micronutrients on Crop Responses and Environmental Sustainability on the Canadian Prairies, Canadian Society of Soil Science, Ottawa, 202-250.

[3] Nyborg, M., Bentley, C.F. and Hoyt, P.B. (1974) Effect of Sulphur Deficiency. Sulphur Institute Journal, 10, 14-15.

[4] Janzen, H.H. and Bettany, J.R. (1984) Sulfur Nutrition of Rapeseed: I. Influence of Fertilizer Nitrogen and Sulfur Rates. Soil Science Society of America Journal, 48, 100-107. http://dx.doi.org/10.2136/sssaj1984.03615995004800010019x

[5] Nuttall, W.F., Ukrainetz, H., Stewart, J.W.G. and Spurr, D.T. (1987) The Effect of Nitrogen, Sulphur and Boron on Yield and Quality of Rapeseed (Brassica napus L. and B. campestris L.). Canadian Journal of Soil Science, 67, 545559. http://dx.doi.org/10.4141/cjss87-051

[6] Grant, C.A., Johnston, A.M. and Clayton, G.W. (2001) Sulphur Fertilizer Forms and Placements for Canola. Proceedings of Manitoba Agronomists Conference 2000, Winnipeg, 12-13 December 2000, 51-59.

[7] Malhi, S.S. (2005) Influence of Four Successive Annual Applications of Elemental S and Sulphate-S Fertilizers on Yield, S Uptake and Seed Quality of Canola. Canadian Journal of Plant Science, 85, 777-792. http://dx.doi.org/10.4141/P04-133

[8] Malhi, S.S., Schoenau, J.J. and Vera, C.L. (2008) Feasibility of Elemental S Fertilizers for Optimum Seed Yield and Quality of Canola in the Parkland Region of the Canadian Great Plains. Chapter in Khan, N.A. and Singh, S., Eds., Sulfur Assimilation and Abiotic Stress in Plants, Springer-Verlag, Berlin, Heidelberg, 21-41. http://dx.doi.org/10.1007/978-3-540-76326-0_2

[9] Solberg, E.D., Malhi, S.S., Nyborg, M. and Gill, K.S. (2003) Fertilizer Type, Tillage, and Application time Effects on Recovery of Sulfate-S from Elemental Sulfur Fertilizers in Fallow Field Soils. Communications in Soil Science and Plant Analysis, 34, 815-830. http://dx.doi.org/10.1081/CSS-120018977

[10] Karamanos, R.E. and Janzen, H.H. (1991) Crop Response to Elemental Sulfur Fertilizers in Alberta. Canadian Journal of Soil Science, 71, 213-225. http://dx.doi.org/10.4141/cjss91-021

[11] Malhi, S.S., Solberg, E.D. and Nyborg, M. (2005) Influence of Formulation of Elemental S Fertilizer on Yield, Quality and S Uptake of Canola Seed. Canadian Journal of Plant Science, 85, 793-802. http://dx.doi.org/10.4141/P04-134

[12] Malhi, S.S., Gan, Y. and Raney, J.P. (2007) Yield, Seed Quality, and Sulfur Uptake of Brassica Oilseed Crops in Response to Sulfur Fertilization. Agronomy Journal, 99, 570-577. http://dx.doi.org/10.2134/agronj2006.0269

[13] Malhi, S.S., Coulman, B. and Schoenau, J.J. (2009) Maximizing Timothy Forage Yield and Quality by Balanced Nitrogen, Phosphorus and Sulphur Fertilization. Agronomy Journal, 101, 1182-1189. http://dx.doi.org/10.2134/agronj2009.0051

[14] Association of Official Analytical Chemists (AOAC) (1990) Fat (Crude) or Ether Extract in Animal Feed (920.39). Official Methods of Analysis, 15th Edition, AOAC, Washington DC.

[15] Huang, C.L. and Schulte, E.E. (1985) Digestion of Plant Tissue for Analysis by ICP-AES. Communications in Soil Science and Plant Analysis, 16, 943-958. http://dx.doi.org/10.1080/00103628509367657

[16] Association of Official Analytical Chemists (AOAC) (1995) Protein (Crude) in Animal Feed. Combustion Method 
(990.03). Official Methods of Analysis, 16th Edition, AOAC, Washington DC.

[17] Williams, P., Sobering, D. and Antoniszyn, J. (1998) Protein Testing Methods. In: Fowler, D.B., Geddes, W.E., Johnston, A.M. and Preston, K.R., Eds., Wheat Protein Production and Marketing, University Extension Press, University of Saskatchewan, Saskatoon, 37-47.

[18] Snyder, C.S. and Bruulsema, T.W. (2007) Nutrient Use Efficiency and Effectiveness in North America. Indices of Agronomic and Environmental Benefits. IPNI Publication Ref. \# 07076, International Plant Nutrient Institute, Norcross.

[19] Combs, S.M., Denning, J.L. and Frank, K.D. (1998) Sulphate-Sulfur. In: Recommended Chemical Soil Test Procedures for the North Central Region, Missouri Agric. Expt. Sta. Publication No. 221 (Revised), Extension and Agricultural Information, I-98 Agricultural Building, University of Missouri, Columbia, 35-59.

[20] Maynard, D.G. and Kalra, Y.P. (1993) Nitrate and Exchangeable Ammonium Nitrogen. In: Carter, M.R., Ed., Soil Sampling and Methods of Analysis, Canadian Society of Soil Science, Lewis Publishers, Ann Arbor, 25-31.

[21] Technicon Industrial Systems (1973) Nitrate in Water and Waste Water. Industrial Method No. 100-70W-B. Revised January 1978, Technicon Industrial Systems, Tarrytown.

[22] SAS Institute, Inc. (2004) Online Documentation for SAS, Version 8. [Online] http://support.sas.com/documentation/onlinedoc/index.html

[23] Malhi, S.S. and Gill, K.S. (2007) Interactive Effects of N and S Fertilizers on Canola Yield and Seed Quality on S-Deficient Gray Luvisol Soils in Northeastern Saskatchewan. Canadian Journal of Plant Science, 87, 211-222. http://dx.doi.org/10.4141/P05-218

[24] Jackson, G.D. (2000) Effects of Nitrogen and Sulfur on Canola Yield and Nutrient Uptake. Agronomy Journal, 92, 644-649. http://dx.doi.org/10.2134/agronj2000.924644x

[25] Malhi, S.S. and Gill, K.S. (2002) Effectiveness of Sulphate-S Fertilization at Different Growth Stages for Yield, Seed Quality and S Uptake of Canola in Northeastern Saskatchewan. Canadian Journal of Plant Science, 82, 665-674. http://dx.doi.org/10.4141/P01-184

[26] Grant, C.A., Clayton, G.W. and Johnston, A.M. (2003) Sulphur Fertilizer and Tillage Effects on Canola Seed Quality in the Black Soil Zone of Western Canada. Canadian Journal of Plant Science, 83, 745-758. http://dx.doi.org/10.4141/P02-107

[27] Grant, C.A., Johnston, A.M. and Clayton, G.W. (2003) Sulphur Fertilizer and Tillage Effects on Early Season Sulphur Availability and N:S Ratio in Canola in Western Canada. Canadian Journal of Plant Science, 83, 451-463. 
Scientific Research Publishing (SCIRP) is one of the largest Open Access journal publishers. It is currently publishing more than 200 open access, online, peer-reviewed journals covering a wide range of academic disciplines. SCIRP serves the worldwide academic communities and contributes to the progress and application of science with its publication.

Other selected journals from SCIRP are listed as below. Submit your manuscript to us via either submit@scirp.org or Online Submission Portal.
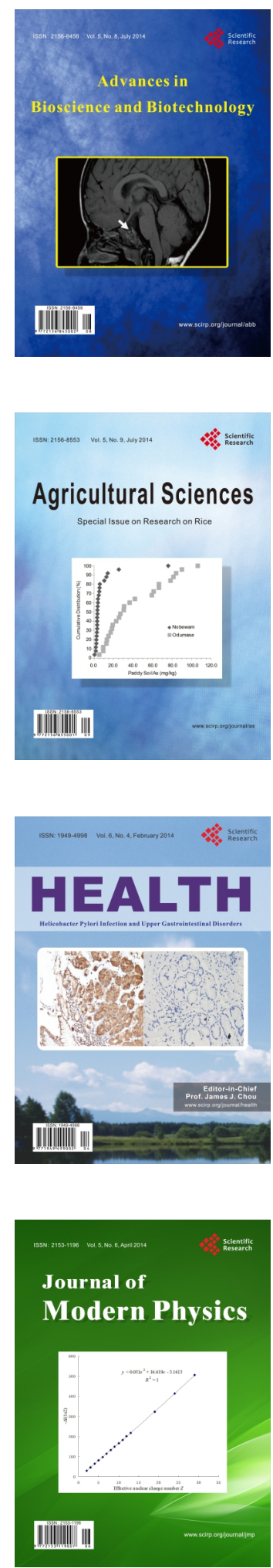
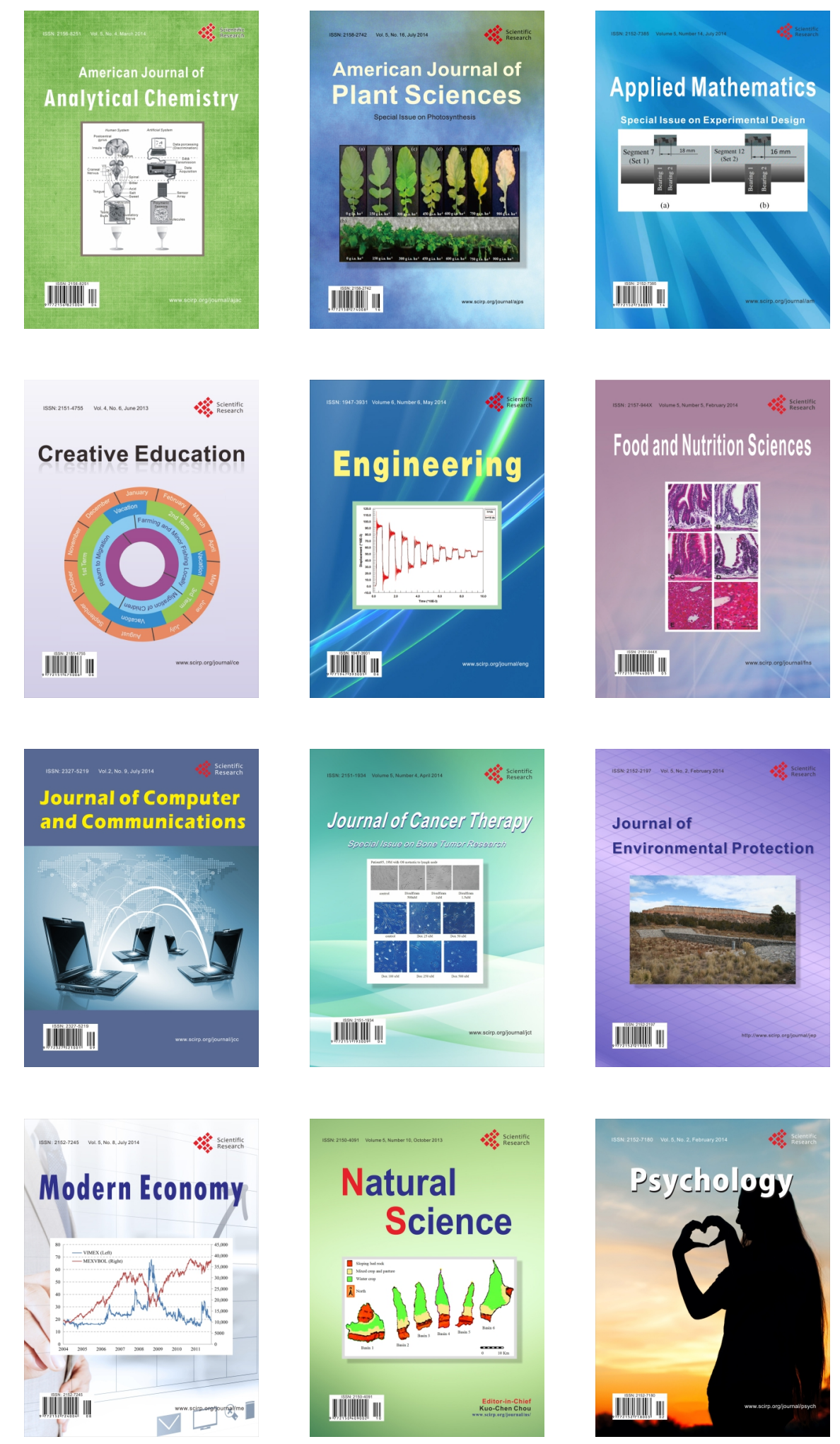